\title{
EFFECT OF DRIED YEAST (Saccharomyces cerevisiae) SUPPLEMENTATION AS FEED ADDITIVE TO LAYING HEN DIET ON EGG PRODUCTION, EGG QUALITY, CARCASS TRAITS AND BLOOD CONSTITUENTS.
}

\author{
Sanaa H.M. Elnagar \\ Department of Animal and Poultry Production, Faculty of Agriculture, South Valley University, 83523 Qena, \\ Egypt, (elnagar4arm@yahoo.com)
}

\section{SUMMARY}

This study was conducted to investigate the effect of different levels of yeast supplementation to laying hen diet on egg production, egg quality, carcass traits and blood constituents. One hundred and eight 26-weeks old, commercial Hy-line Brown hens were randomly assigned into 3 groups, (six replicates of six birds each). The basal diet was formulated to meet requirements of layers and supplemented with dried yeast (Saccharomyces cerevisiae) at levels of 0,3 or $6 \mathrm{~g} / \mathrm{kg}$ feed and fed for four months.

Results showed that yeast supplementation at levels of 3 or $6 \mathrm{~g} / \mathrm{kg}$ feed significantly decreased hen/day egg production, egg number and feed consumption. Dried yeast at $6 \mathrm{~g} / \mathrm{kg}$ diet tends to decrease live weight, heart weight and plasma total protein. In conclusions yeast supplementation significantly increased shell thickness and improved shell\% and yolk. Meanwhile, haugh unit, albumin, egg shape index and yolk index did not significantly affect.

\section{Keywords: Laying hens, yeast, performance, blood constituents, carcass traits, egg quality}

\section{INTRODUCTION}

Feed additives were used in poultry industry for different purposes, for example to increase performance and decrease mortality rate. These additives include probiotics, coccidiostates and etc. (Afshare - Mazandaran and Rajab, 2001 and Panda et al., 2000). Probiotics are live microorganisms that, when administered through the digestive tract, have a positive impact on the host's health. Microorganisms used in animal feed are mainly bacterial strains belonging to different genera, e.g. Lactobacillus, Enterococcus, Pediococcus and Bacillus. Other probiotics are microscopic fungi, including Saccharomyces yeasts. Some probiotic microorganisms are normally resident in the digestive tract, while others are not (Guillot, 2009). Yousefi and Karkoodi (2007) studied the effect of the addition of different levels of probiotic $(0.05$, 0.1 and $0.15 \%$ ) and Saccharomyces cerevisiae $(0.05,0.1$ and $0.15 \%)$ to laying hens diet at 63 week of age. The results showed that body weight changes, feed intake, feed conversion ratio, egg production, egg weight, shell percent and albumin weight did not indicate any treatment effect $(\mathrm{P}>0.05)$. However; shell weight, shell thickness, yolk weight and yolk cholesterol was significantly different among treatment groups. Yolk cholesterol was lower in some treatments compared to the control. Yalcin et al. (2008b) investigated the effects of yeast culture (Saccharomyces cerevisiae) at levels 0 and $2 \mathrm{~g} / \mathrm{kg}$ supplemented to Lohman Brown laying hen ( 21 wk of age) diets containing two oilseed meals and fed for $16 \mathrm{wk}$ on performance, egg traits, and some blood parameters. They found that yeast culture supplemented to diets containing oilseed meals did not significantly affect feed intake, hen-day egg production, feed efficiency, interior and exterior egg quality characteristics, and serum levels of total protein, triglycerides, cholesterol, alanine amino transferase, aspartate amino transferase, and alkaline phosphatase. However, body weight gain, egg weight, and serum uric acid were increased with yeast culture supplementation. The reduction in egg yolk cholesterol was significant in the groups fed yeast supplemented diets.

Working on laying hens, Dizaji and Pirmohammadi (2009) determined the effect of dietary probiotic containing Saccharomyces cerevisiae on body weight, daily feed consumption, egg production, egg weight, egg mass and feed conversion. In 10 weeks experimental period, hens (46 to 55 weeks of age) were allocated to four dietary treatments $(0, \quad 200, \quad 300, \quad 400 \mathrm{~g}$ Saccharomyces cerevisiae/ton of diet). Using yeast caused significant improve in feed conversion and significant decrease in egg weight, however, it had no significant effect on the other parameters.

Yalcin et al. (2010) determined the effects of yeast autolysate (Saccharomyces cerevisiae, Inte Wall) at levels of 1, 2, 3 and $4 \mathrm{~g} \mathrm{~kg}-1$ in the diets of Hyline Brown laying hens, 22 weeks of age. Dietary treatments did not significantly affect body weight, feed intake and egg traits. Yeast autolysate supplementation increased egg production, egg weight, and feed efficiency but, decreased egg yolk cholesterol, blood serum cholesterol and triglycerides, and increased antibody titres to sheep red blood cells. Total saturated fatty acids and the ratio of unsaturated/saturated fatty acids increased and monounsaturated fatty acids decreased with yeast autolysate supplementation. This study aimed to investigate the effect of dried yeast 
supplementation to the diet of commercial laying hens (Hy-line brown) on performance, egg quality, carcass traits and some blood constituents

\section{MATERIALS AND METHODS}

\section{Management and Feeding}

This study was carried out at the Poultry Research Farm, Faculty of Agriculture, South Valley University, Qena, The trial was conducted for four months between January, 2010 and April, 2010 in controlled closed system house. One hundred and eight 26-weeks old, commercial Hyline Brown hens were randomly assigned into 3 groups, each group contains six replicates of six birds per each. Each replicate was kept in wire cage of 61 × $55 \times 45 \mathrm{~cm}$. The basal diet (Table 1) was formulated to meet requirements of layers according to NRC (1994), and supplemented with dried yeast (Saccharomyces cerevisiae) at three levels being 0,3 or $6 \mathrm{gm} / \mathrm{kg}$ feed.

Table 1. Composition and calculated analysis of the basal diet

\begin{tabular}{lc}
\hline Ingredients & $\%$ \\
\hline Yellow corn & 61.50 \\
Soy bean meal $(44 \%)$ & 20.00 \\
Corn gluten meal $(60 \%)$ & 7.00 \\
Wheat bran & 0.45 \\
Vit. \& Min. premix* & 0.30 \\
Dicalcium phosphate & 1.36 \\
Calcium carbonate & 8.95 \\
NaCl & 0.40 \\
DL-methionine & 0.04 \\
Total & 100 \\
Calculated analysis: & \\
ME (Kcal/Kg) & 2766 \\
Crude Protein $(\%)$ & 18.45 \\
Crude fiber $(\%)$ & 2.82 \\
Calcium $(\%)$ & 3.80 \\
Phosphours $(\%)$ & 0.62 \\
\hline
\end{tabular}

Each diet was supplied with $3 \mathrm{~kg} /$ ton Vit. \& Min. Mix (commercial source B. p. Max) Each $3 \mathrm{~kg}$ contains,

Vit. A 10, 000,000 MIU, Vit. D 2, 000,000 MIU, Vit. E 10000 mg, Vit. K3 1000 mg, Vit. B1 1000 mg, Vit. B2 $5000 \mathrm{mg}$, Vit. B6 $1500 \mathrm{mg}$, Biotin $50 \mathrm{mg}$, BHT 10000 $\mathrm{mg}$, Pantothenic $10000 \mathrm{mg}$, folic acid $1000 \mathrm{mg}$, Nicotinic acid 30000 mg Mn 60 g, Zinc 50 g, Fe 30 g, Cu 4 g, I 3 g, Selenium $0.1 \mathrm{~g}$ and Co $0.1 \mathrm{~g}$.

\section{Measurements}

The hen performance of the experimental groups was determined through evaluating the feed intake, feed conversion ratio, egg weight and egg number. Egg quality was estimated by measuring shape index, shell thickness, yolk index, and percentage of shell, yolk and albumen as well as Haugh Unit using egg samples obtained from each replicate on the last three successive days of each month.

Blood samples were collected from brachial vein of 18 hens randomly chosen from each treatment (three from each replicate) at the end of the experiment and centrifuged at $3000 \mathrm{rpm}$ for 20 minutes. Serum was collected and stored at $-20^{\circ} \mathrm{C}$ for determination of total protein (TP), albumen (Alb), globulin (Glo), albumen/ globulin ratio (AGr), triglycerides (Tri), total cholesterol (Tchol), glucose (Gluc), alanine amino transferase (ALT), aspartate amino transferase (AST), alkaline phosphatase (ALP , calcium $(\mathrm{Ca})$ and phosphorus (p) using commercial kits. At the end of the experiment, six hens from each treatment representing the average body weight of each treatment were slaughtered. After slaughtering and complete bleeding, the birds were scalded and feathers were mechanically plucked. Carcass was eviscerated then; feet, head, neck and shanks were removed. Then the carcasses were immediately weighed to obtain post-slaughter carcass weight without giblets. Giblets (included liver, heart and gizzard) as well as abdominal fat, ovary and oviduct were weighed. Also, oviduct length and intestine length were measured.

\section{Statistical Analysis}

Data were analyzed using the general linear model procedure of SAS User's Guide (SAS Institute, 2005). Significant treatment effects were detected by Duncan's multiple range test (Duncan, 1955).

\section{RESULTS AND DISCUSSION}

\section{Productive performance}

As shown in Table(2), there were significant decreased $(\mathrm{P} \leq 0.05)$ in hen-day egg production and egg number, as dietary dried yeast supplementation.

However, there were no significant effects ( $P$ $\geq 0.05$ ) on egg weight, egg mass and feed conversion ratio due to yeast supplementation compared to the control. Average feed consumption of the control group was significantly $(\mathrm{P}<0.05)$ higher compared to those hens fed diet supplemented with either 3 or $6 \mathrm{~g}$ yeast $/ \mathrm{kg}$ diet. The presented data agree with those of Hewida et al. (2011) who reported that increased levels of yeast culture supplementation significantly decreased hen-day egg production. Hosseini et al. (2006) found that the addition of live yeast had no positive effect on egg production, egg weight, egg mass, but it had significant effect on feed conversion at 25-78 weeks. On the other hand, other studies reported an improved egg production $(\mathrm{P}<0.05)$ due to yeast culture supplementation (Abou El-Ella et al., 1996 and Liu and Yoon, 2002). Supplementation of yeast at $2 \mathrm{~kg} / \mathrm{ton}$ feed $(0.2 \%)$ resulted in a significant increase $(\mathrm{P}<0.05)$ in egg weight and consequently increased egg mass. Liu and Yoon (2002) and Nursoy et al. (2004) reported no effect of dietary yeast culture on feed consumption, egg production, egg weight, and feed efficiency in laying hens. In this connection, Dizaji and Pirmohammadi (2009) found a significant improve in feed conversion and a significant decrease in egg weight, without 
significant effect on the other parameters, due to supplementing Saccharomyces cerevisiae at 0, 200, 300 and $400 \mathrm{~g} /$ ton of laying hen diet.

The cause of no benefit of dried yeast supplementation on performance of laying hens may be due to excess of yeast with normal levels of vitamin mixture resulted in negative interaction or, it's returned to birds, diets, methods and the chemical composition of dietary ingredients that include soybean meal and yellow corn with low fiber content so, dried yeast did not affect hen performance because it needs the diet to contain high fiber content to encourage microbial digestion by increasing flora in laying hen gut.

Table 2. Effect of dried yeast supplementation on performance of laying hens

\begin{tabular}{lcccc}
\hline & Control & $\mathbf{T}_{\mathbf{1}}(\mathbf{3}$ g yeast $/ \mathbf{k g})$ & $\mathbf{T}_{\mathbf{2}}(\mathbf{6}$ g yeast $/ \mathbf{k g})$ & P value \\
\hline Hen-day egg prod\% & $65.22^{\mathrm{a}} \pm 0.43$ & $60.08^{\mathrm{b}} \pm 0.37$ & $61.83^{\mathrm{b}} \pm 0.43$ & 0.0449 \\
Egg number/hen \% & $78.26^{\mathrm{a}} \pm 0.65$ & $72.10^{\mathrm{b}} \pm 0.57$ & $74.20^{\mathrm{b}} \pm 1.31$ & 0.0449 \\
Egg weight (g) & $58.13 \pm 0.59$ & $57.43 \pm 0.34$ & $57.15 \pm 0.44$ & 0.4433 \\
Egg mass /hen (g) & $45.49 \pm 15.98$ & $41.41 \pm 3.23$ & $42.41 \pm 7.39$ & 0.3194 \\
Feed consumption (g/hen) & $130.47^{\mathrm{a}} \pm 10.55$ & $125.06^{\mathrm{b}} \pm 17.77$ & $124.69^{\mathrm{b}} \pm 15.40$ & 0.0386 \\
Feed conversion $(\mathbf{g} / \mathbf{g})$ & $2.87 \pm 0.13$ & $3.02 \pm 0.02$ & $2.94 \pm 0.06$ & 0.4557 \\
\hline
\end{tabular}

$\mathrm{a}, \mathrm{b}$ means within row at each criterion bearing different superscripts are significantly different $(\mathrm{P} \leq 0.05$ )

\section{Carcass traits}

Data presented in Table (3) showed that yeast supplementation to laying hens diet at the level of $6 \mathrm{~g} / \mathrm{kg}$ diet significantly decreased live body weight and weight of heart compared with the control and $\mathrm{T} 1$. This may be returned to low energy level and high protein value for a period of experiment and the decrease in feed consumption. These results disagree with those of Yalcin et al. (2008b) who found that body weight increased with yeast supplementation. However, there were no significant differences in the other studied carcass traits and not due to yeast treatment.

\section{Egg quality}

Results in Table (4) showed that feeding diets supplemented with dried yeast at levels of 3 or 6 $\mathrm{g} / \mathrm{kg}$ diet had significantly increased $(\mathrm{P} \leq 0.05)$ shell thickness, however, there were no significant differences between treatments regarding shell \%,
HU, yolk\%, egg shape index and yolk index. On the other hand, dried yeast supplementation at 3 or $6 \mathrm{~g} / \mathrm{kg}$ diet tends to decrease albumin $\%$ as compared to the control hens. These results are in agreement with those of Yalcin et al. (2008b) who found that yeast culture did not significantly affect interior and exterior egg quality characteristics. However, Hosseini et al. (2006) found that the addition of live yeast at levels of $0.0 .25,0.50,0.75$ and $1 \mathrm{~g}$ live yeast $/ \mathrm{kg}$ feed had no positive effect on egg shell thickness and egg shell strength at 25-32 weeks, while Haugh unit was higher than the control at all experimental periods. Also, Yousefi and Karkoodi (2007) studied the effect of the addition of different levels of probiotic $(0.05,0.1$ and $0.15 \%)$ and Saccharomyces cerevisiae (0.05, 0.1 and $0.15 \%$ ) to laying hens diet at 63 week of age. Their results revealed that shell percent and albumin weight did not indicate any treatment effect $(\mathrm{P}>0.05)$. While shell weight, shell thickness, yolk weight and yolk cholesterol were significantly different among the treatment groups.

Table 3. Effect of dried yeast supplementation on carcass characteristics of laying hens

\begin{tabular}{|c|c|c|c|c|c|c|c|c|c|}
\hline Item & $\begin{array}{c}\text { Live } \\
\text { weight } \\
\text { (g) }\end{array}$ & $\begin{array}{c}\text { Ovary } \\
\text { weight } \\
\text { (g) }\end{array}$ & $\begin{array}{c}\text { Oviduc } \\
\text { t weight } \\
\text { (g) }\end{array}$ & $\begin{array}{c}\text { Oviduct } \\
\text { length } \\
(\mathrm{cm})\end{array}$ & $\begin{array}{l}\text { Intestine } \\
\text { length } \\
(\mathrm{cm})\end{array}$ & $\begin{array}{c}\text { Liver } \\
\text { weight } \\
\text { (g) }\end{array}$ & $\begin{array}{c}\text { Gizzard } \\
\text { weight } \\
\text { (g) }\end{array}$ & $\begin{array}{c}\text { Heart } \\
\text { weight } \\
\text { (g) }\end{array}$ & $\begin{array}{c}\text { Abdominal } \\
\text { fat } \\
\text { (g) }\end{array}$ \\
\hline $\mathbf{C}$ & $\begin{array}{c}1720 \\
\pm \\
25.37^{\mathrm{a}}\end{array}$ & $\begin{array}{c}43.63 \\
\pm \\
4.61\end{array}$ & $\begin{array}{c}68.71 \\
\pm \\
5.35\end{array}$ & $\begin{array}{c}61.83 \\
\pm \\
0.83\end{array}$ & $\begin{array}{c}153.00 \\
\pm \\
3.36\end{array}$ & $\begin{array}{c}39.32 \\
\pm \\
3.07\end{array}$ & $\begin{array}{c}33.82 \\
\pm \\
2.67\end{array}$ & $\begin{array}{c}7.44 \\
\pm \\
0.63^{\mathrm{a}}\end{array}$ & $\begin{array}{c}25.66 \\
\pm \\
2.41\end{array}$ \\
\hline T1 & $\begin{array}{c}1652 . \\
\pm \\
39.63^{\mathrm{a}}\end{array}$ & $\begin{array}{c}45.69 \\
\pm \\
3.15\end{array}$ & $\begin{array}{c}69.36 \\
\pm \\
5.49\end{array}$ & $\begin{array}{c}59.33 \\
\pm \\
1.52\end{array}$ & $\begin{array}{c}160.33 \\
\pm \\
6.51\end{array}$ & $\begin{array}{c}35.28 \\
\pm \\
2.88\end{array}$ & $\begin{array}{c}33.99 \\
\pm \\
4.02\end{array}$ & $\begin{array}{c}7.07 \\
\pm \\
0.22^{\mathrm{a}}\end{array}$ & $\begin{array}{c}22.09 \\
\pm \\
4.03\end{array}$ \\
\hline $\mathbf{T 2}$ & $\begin{array}{c}1532 . \\
\pm \\
5.89^{b}\end{array}$ & $\begin{array}{c}43.98 \\
\pm \\
5.89\end{array}$ & $\begin{array}{c}68.79 \\
\pm \\
6.81\end{array}$ & $\begin{array}{c}59.83 \\
\pm \\
0.87\end{array}$ & $\begin{array}{c}152.16 \\
\pm \\
10.02\end{array}$ & $\begin{array}{c}30.79 \\
\pm \\
2.03\end{array}$ & $\begin{array}{c}27.26 \\
\pm \\
1.20\end{array}$ & $\begin{array}{c}5.11 \\
\pm \\
0.16^{\mathrm{b}}\end{array}$ & $\begin{array}{c}17.95 \\
\pm \\
3.45\end{array}$ \\
\hline$P$ value & 0.0121 & 0.9467 & 0.9964 & 0.2785 & 0.6821 & 0.1159 & 0.2030 & 0.0019 & 0.2982 \\
\hline
\end{tabular}

a, b means within row at each item bearing different superscripts are significantly different ( $\mathrm{P} \leq 0.05)$. 
Table 4. Effect of dried yeast supplementation on egg quality of laying hens

\begin{tabular}{lrrrc}
\hline & \multicolumn{1}{c}{ C } & \multicolumn{1}{c}{ T1 } & \multicolumn{1}{c}{ T2 } & P value \\
\hline Shell \% & $14.09 \pm 0.22$ & $15.13 \pm 0.48$ & $14.13 \pm 0.27$ & $\mathbf{0 . 0 6 3 6}$ \\
Shell thickness $(\boldsymbol{\mu m})$ & $373.50 \pm 4.61^{\mathrm{b}}$ & $390.94 \pm 4.91^{\mathrm{a}}$ & $378.33 \pm 5.21^{\mathrm{ab}}$ & $\mathbf{0 . 0 4 2 8}$ \\
Haugh unit & $88.89 \pm 1.09$ & $87.65 \pm 0.92$ & $87.54 \pm 1.08$ & $\mathbf{0 . 5 9 6 8}$ \\
Albumin \% & $62.17 \pm 0.28^{\mathrm{a}}$ & $60.56 \pm 0.62^{\mathrm{b}}$ & $61.80 \pm 0.47^{\mathrm{ab}}$ & $\mathbf{0 . 0 5 4 7}$ \\
Yolk \% & $23.72 \pm 0.22$ & $24.29 \pm 0.29$ & $24.06 \pm 0.28$ & $\mathbf{0 . 3 1 8 1}$ \\
Egg shape index & $80.18 \pm 0.40$ & $81.38 \pm 0.38$ & $80.21 \pm 0.59$ & $\mathbf{0 . 1 3 1 9}$ \\
Yolk index & $21.53 \pm 0.23$ & $21.23 \pm 0.54$ & $20.76 \pm 0.25$ & $\mathbf{0 . 3 4 5 4}$ \\
\hline
\end{tabular}

$\mathrm{a}, \mathrm{b}$ means within row at each item bearing different superscripts are significantly different $(\mathrm{P} \leq 0.05)$

\section{Blood measurements}

The data in (Table 5) revealed that dried yeast supplemented at the levels of 3 and $6 \mathrm{~g} / \mathrm{kg}$ feed did not significant effect on blood measurements except TP, which was increased probably due to the improvement in protein's metabolism. These results agree with the results of Yalcin et al. (2008 a) who studied the effects of yeast culture supplementation to laying hen diets containing soybean meal or sunflower meal and showed that neither AST nor ALT were affected. Yalcin et al. (2008b) found that yeast culture (Saccharomyces cerevisiae) supplementation at $2 \mathrm{~g} / \mathrm{kg}$ of Lohmann Brown laying hen ( $21 \mathrm{wk}$ of age) diets containing 2 oilseed meals and fed for 16 wk did not significantly increase serum levels of total protein, triglycerides, cholesterol, alanine amino transferase, aspartate amino transferase, and alkaline phosphatase. Also, Hewida et al. (2011) reported that the effect of yeast culture supplementation on blood constituents was not seen for total protein, albumin, globulin and creatinine. Moreover, Ghally and Abd El-Latif (2007) revealed that Japanese quail fed diets contained yeast culture at levels of 1 or $2 \%$ showed an improvement in total protein, albumin, globulin, GOT and GPT of blood plasma when birds fed dietary yeast.

\section{CONCLUSION}

Dried bakery yeast supplementation to laying hen diet did not improve laying hen performance except feed consumption, carcass weight and heart weight only at $3 \mathrm{~g} / \mathrm{kg}$. However, plasma total protein, egg shell, albumen, yolk percentage, shell thickness and yolk index were positively affected by yeast supplementation. Yeast supplementation at levels 3 or $6 \mathrm{~g} / \mathrm{kg}$ feed to low energy level and high protein value diet for a period of 4 months experiment diet did not improve most hen performance terms.

Table 5. Effect of dried yeast supplementation on blood parameters of laying hens

\begin{tabular}{|c|c|c|c|c|c|c|c|c|c|c|c|}
\hline Groups & $\underset{(\mathrm{g} / \mathrm{dl})}{\mathbf{T P}}$ & $\begin{array}{c}\text { Alb } \\
\text { (g/dl) }\end{array}$ & $\begin{array}{l}\text { Glob } \\
\text { (g/dl) }\end{array}$ & $\mathbf{A} / \mathbf{G}$ & $\begin{array}{c}\text { T. } \\
\text { choles } \\
\text { (mg/dl) }\end{array}$ & $\begin{array}{l}\text { Glucose } \\
\text { (mg/dl) }\end{array}$ & $\begin{array}{l}\text { AST } \\
\text { (U/l) }\end{array}$ & $\begin{array}{l}\text { ALT } \\
\text { (U/l) }\end{array}$ & $\underset{(\mathbf{m g} / \mathbf{d l})}{\mathbf{T G}}$ & $\begin{array}{l}\mathrm{Ca} \\
(\mathrm{mg} / \mathrm{dl})\end{array}$ & $\begin{array}{l}P \\
(\mathrm{mg} / \mathrm{dl})\end{array}$ \\
\hline \multirow{3}{*}{ C } & 3.51 & 1.25 & 2.26 & 0.50 & 117.33 & 186.16 & 57.16 & 12.55 & 126.00 & 11.13 & 5.40 \\
\hline & \pm & \pm & \pm & \pm & \pm & \pm & \pm & \pm & \pm & \pm & \pm \\
\hline & $0.07^{\mathrm{ab}}$ & $0 . \overline{0} 6$ & $0 . \overline{10}$ & 0.03 & $2 . \overline{2} 6$ & 1.66 & 1.19 & $0 . \overline{53}$ & $0 . \overline{85}$ & $0 . \overline{17}$ & $0 . \overline{0}$ \\
\hline \multirow{3}{*}{ T1 } & 3.58 & 1.35 & 2.23 & 0.57 & 117.33 & 186.33 & 58.83 & 13.05 & 127.16 & 11.38 & 5.53 \\
\hline & \pm & \pm & \pm & \pm & \pm & \pm & \pm & \pm & \pm & \pm & \pm \\
\hline & $0.03^{\mathrm{a}}$ & 0.02 & 0.02 & 0.02 & 1.62 & 0.95 & 1.95 & 0.56 & 0.47 & 0.07 & 0.11 \\
\hline \multirow{3}{*}{$\mathbf{T} 2$} & 3.36 & 1.28 & 2.08 & 0.47 & 121.00 & 186.83 & 58.00 & 13.71 & 124.83 & 11.53 & 5.36 \\
\hline & \pm & \pm & \pm & \pm & \pm & \pm & \pm & \pm & \pm & \pm & \pm \\
\hline & $0.05^{\mathrm{b}}$ & 0.06 & 0.10 & 0.04 & 1.82 & 1.44 & 2.09 & 0.39 & 1.13 & 0.08 & 0.24 \\
\hline $\begin{array}{l}P \\
\text { value }\end{array}$ & 0.037 & 0.398 & 0.298 & 0.173 & 0.325 & 0.939 & 0.808 & 0.286 & 0.197 & 0.087 & 0.756 \\
\hline
\end{tabular}

a, b means within column at each item bearing different superscripts are significantly different $(\mathrm{P} \leq 0.05)$.

\section{REFERENCES}

Abou El-Ella, M.A., M. Y. Attia, K. Y. El-Nagmy and M.A.H. Radwan, 1996. The productive performance of layers fed diets supplemented with some commercial feed additives. Egyptian Journal of Animal Production. Suppl.33, 423430.
Afshare-Mazandaran, N and A. Rajab, 2001. Probiotics and their applies in animal and poultry nutrition (first edition). Noorbakhsh Express (Tehran).

Dizaji, B. and R. Pirmohammadi, 2009. Effect of Saccharomyces cerevisiae and Bioplus 2B on performance of laying hens. International 
Journal of Agriculture and Biology. vol. 11, no. 4, pp(495-497).

Duncan, D.B., 1955. Multiple ranges and multiple F-test. Biometrisc, 11: 1042.

Ghally, K. A. and S. A. Abd El-Latif, 2007. Effect of dietary yeast on some productive and physiological aspects of growing Japanese quails. African Crop Science Conference Proceedings Vol. 8. 2147-2151 Printed in ElMinia, Egypt.

Guillot, J.F, 2009. Consequences of probiotics release in the intestine of animals. Universite de tours- IUT, reve du pant- Volant, 37082, France.

Hewida, H.M.A., M.H. El-Allawy and A.A. ElGhamry, 2011. The Effect of (Yeast Saccharomyces cerevisiae) culture versus flavomycin supplementation on laying hen diets and their co-mparative influence on the late stage production performnce. Iranian Journal of Applied Animal Science Volume: 1; 3:149-153

Hosseini, S.A., H. Lotfollahian, A. Kamyab and A. Mahdavi, 2006. Study on the effect of yeast (Saccharomyces cerevisiae SC47) utilization on the commercial layer hen's performance. Pakistan Journal of Biological Sciences, 9(12) 2346-2349.

Liu, Z., Q. Qi and I. Yoon, 2002. Effect of yeast culture on production parameters and intestinal microflora in laying hens. Poult. Sci. Association, 91 ${ }^{\text {th }}$ Annual Meeting Abstracts, August 11-14, 2002, Newark, DE.

NRC , 1994. National Research Council. Nutrient requirements of poultry. $9^{\text {th }}$ Ed. National Academy Press, Washington, DC.

Nursoy, H., O. Kaplan, M. N. Ođuz, and O. Yilmaz, 2004. Effects of varying levels of live yeast culture on yield and some parameters in laying hen diets. Indian Veterinary Journal, 81:59-62.

Panda, A.K., M. R. Reddy, S.V. Rama Rao , M.V. L.N. Raju, and N. K. Paraharaj, 2000 . Growth, carcass characteristics, immunocomponence and response to Esherchia coli of broiler fed diets with various level of probiotic. Archiv für Geflügelkunde, 64:152-156.

SAS, 2005. SAS User's Guide, Statistics (9.1 ${ }^{\text {th }}$ Ed.) Cary NC: SAS Institute Inc.

Yalcin, S., B. Ozsoy El-Erol and S. Yalcin, 2008 a. Yeast culture supplementation to laying hen diets containing soybean meal or sunflower seed meal and its effect on performance, egg quality traits and blood chemistry. Journal of Applied Poultry Research, 17, 229-236.

Yalcın, S., F. Oguz, B. Guçlu and S. Yalcın, 2008 b. Effects of dietary dried baker's yeast on the performance, egg traits and blood parameters in laying quails. Tropical Animal Health and Production, (2009) 41:5-10.

Yalcın, S., S. Yalcın, Kemal Cakın, O. Eltan and L. Dagasan, 2010. Effects of dietary yeast autolysate (Saccharomyces cerevisiae) on performance, egg traits, egg cholesterol content, egg yolk fatty acid composition and humoral immune response of laying hens. Journal of the Science of Food and Agriculture, 290: 1695-1701.

Yousefi, M. and K. Karkoodi, 2007. Effect of probiotic thepax ${ }^{\circledR}$ and Saccharomyces cerevisiae supplementation on performance and rgg quality of laying hens. International Journal of Poultry Science 6 (1): 52-54.

تأثير إضافة الخميرة الجافة (خميرة الخباز) إلى عليقة دجاج البيض على الأداء الإنتاجى، جودة البيض، خصائص

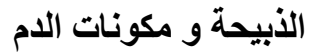
سناء النجار قسم الانتاج الحيوانى، كلية زراعة، جامعة جنوب الوادى، قنا

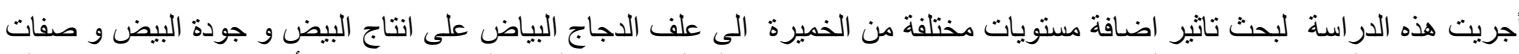

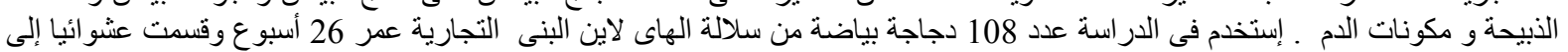

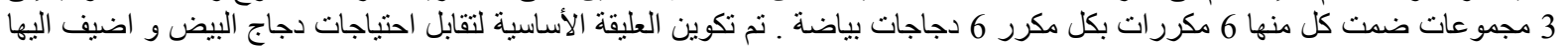

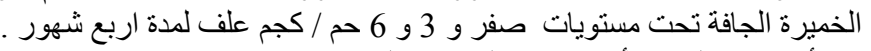

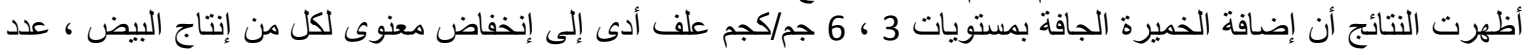

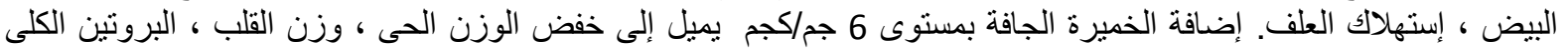

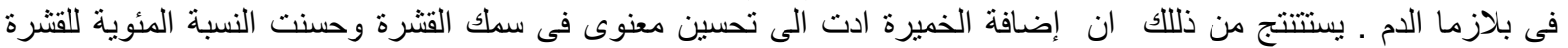
و الصفار بينما لم تتأثر معنوى ارتفاع البياض و الالبيومين ودليل شكل البيضه ودليل الصفار الين فين 